\title{
The Role of NGO In Community Empowerment (Case Study LPPSLH Penderes Empowerment in Pasinggangan Village, Banyumas Regency)
}

\author{
Dita Aprilia ${ }^{1)}$, Ageng Widodo ${ }^{2)}$ \\ ${ }^{1}$ Universitas Islam Negeri Prof. K.H. Saifuddin Zuhri Purwokerto, Indonesia (apriliadita02@gmail.com) \\ ${ }^{2}$ Universitas Islam Negeri Prof. K.H. Saifuddin Zuhri Purwokerto, Indonesia (widodoageng009@gmail.com
}

\begin{abstract}
Behind the life that we see in the capital city, it turns out that we still know the phenomenon of people's lives in rural areas who still depend on the natural resources around them. One of them is the phenomenon of coconut sugar farmers, who are often called penderes, who still cannot process coconut sap correctly and adequately to increase the selling value of the sugar. It is due to the low level of education and the lack of public knowledge in processing coconut sugar. LPPSLH is a non-government institution engaged in community empowerment, both urban and rural. With the phenomenon experienced by the farmers, LPPSLH as a facilitator, invites the farmers to take part in the organic certification program for ant sugar. Later, it can increase the farmers' income, increase the selling value of sugar, and market their products to the export market. The training and assistance aim to change farmers' behavior and old habits into more productive and profitable habits (efforts) to build farmers' independence. The method used in this research is descriptive-qualitative, and the sampling was collected purposively. The data collection technique used interviews, observation, and documentation. The results showed that LPPSLH played the role of education, facilitation, and advocacy to penderes farmers in empowerment programs, especially in rural areas.
\end{abstract}

Keywords: Role of GNO, Community Empowerment, Organic Certification, Penderes

\section{ABSTRAK}

Di balik kehidupan yang kita saksikan di kota besar, ternyata kita masih mengetahui fenomena kehidupan masyarakat di pedesaan yang masih bergantung pada sumber daya alam yang ada di sekitarnya. Salah satunya adalah fenomena petani gula kelapa yang sering disebut penderes masih belum 
bisa mengolah nira kelapa secara benar dan memadai untuk meningkatkan nilai jual gula tersebut. Hal ini disebabkan rendahnya tingkat pendidikan dan kurangnya pengetahuan masyarakat dalam mengolah gula kelapa. LPPSLH merupakan lembaga non pemerintah yang bergerak di bidang pemberdayaan masyarakat, baik perkotaan maupun pedesaan. Dengan fenomena yang dialami petani, GNO sebagai fasilitator mengajak petani untuk mengikuti program sertifikasi organik gula semut. Nantinya dapat meningkatkan pendapatan petani, meningkatkan nilai jual gula, dan memasarkan produknya ke pasar ekspor. Pelatihan dan pendampingan tersebut bertujuan untuk mengubah perilaku dan kebiasaan lama petani menjadi kebiasaan (upaya) yang lebih produktif dan menguntungkan untuk membangun kemandirian petani. Metode yang digunakan dalam penelitian ini adalah deskriptif-kualitatif, dan pengambilan sampel dilakukan secara purposive. Teknik pengumpulan data menggunakan wawancara, observasi, dan dokumentasi. Hasil penelitian menunjukkan bahwa GNO berperan dalam pendidikan, fasilitasi, dan advokasi kepada petani penderes dalam program pemberdayaan khususnya di pedesaan.

Kata Kunci: Peran GNO, Pemberdayaan Masyarakat, Sertifikasi Organik, Penderes

\section{INTRODUCTION}

Empowerment is a tool used to see the existing potential in the community. A group of people does it with different motives. According to Merriam Webster, the concept of empowerment is to give power or authority (to give strength, transfer power, or delegate to other parties) and to give the ability or empowerment (Bambang Kuncoro, 2004).

In the empowerment process, the object is often the rural community. The Indonesian territory is mainly composed of rural areas where rural communities tend to be considered as a group of people who are still traditional. For this reason, it must be adapted to nature and directed to science and technology development. So that rural communities recognize the process of industrialization in urban areas. Second, the socio-economic conditions of rural communities are still problematic. Inequality, poverty, and social inequalities still occur in many villages because human resources are still relatively low (Bambang Kuncoro, 2004).

Such conditions are the reasons for the empowerment of rural communities. Underdevelopment in the village causes inequality and poverty between communities. Then the culture in the village community also triggers the mindset and character of the community in the village. The objectives of empowering rural communities are as follows: (1) Develop and strengthen the process of implementing government decentralization and assisting in accelerating and recovering from the impact of the crisis. (2) The empowerment of rural communities to take an active role in regional development. (3) Improve the district's transparency, administration, supervision, accounting, and reporting procedures. (4) Eradicating poverty through increasing access of the poor to essential public services. (5) Create jobs and encourage economic activity at 
the local level. (6) Improving the function of basic facilities and infrastructure (Mashuri Maschab, 1992).

In an economic sense, the village is a place to live in a family in a group of houses with significant interdependence in the social and economic fields. Villages consist of farming households with production, consumption, and investment activities resulting from joint family decisions (Hayami Yujiro dan Masao Kikuchi, 1987: 11). Empowerment at the village level is a process towards independence in rural communities. Some elements or components make up the village as a state administrative unit that produces swakarsa, swakarya, dan swadaya of village communities.

The plantation is one of the potential sub-sectors in Indonesia and coconut is a commodity developed as a raw material for the coconut sugar industry. Banyumas Regency is the largest producer of coconut sugar in Indonesia. One of them is Pasinggangan Village, Banyumas subdistrict. As a coconut sugar-producing area and the majority of its people are farmers, it should provide a prosperous life for coconut sugar farmers. Coconut sugar farmers, often called penderes, climb coconut trees to take their juice that has not yet become a coconut. Penderes usually take coconut sap twice a day. After taking the sap, the penderes cook or process the sap into coconut sugar.

Coconut sugar is currently one of the most important commodities in Indonesia, and its sales are now penetrating the international market. However, the life of penderes or coconut sugar farmers is still far from prosperous because of their limited circumstances, low level of education, and lack of knowledge on how to process coconut sugar, and their inability to access the market. Those things are affected to be unable to determine and control the price of coconut sugar. It is also often monopolized by the powerful parties and causes coconut sugar farmers to depend on collectors. Collectors' dependencies cause farmers to have a low position. It makes sugar prices unstable. So that's why penderes are still lined with a low economy and less prosperous.

Social assistance is a strategy that will determine the success of community empowerment programs. By the principle of social work, such as helping people to help themselves, community empowerment is very concerned about the importance of strong public participation. In this context, the role of social workers is often manifested in the capacity of a companion, not as a healer or problem solver directly. After briefly discussing the concept of social assistance, successively discuss the tasks areas or social assistance functions, the role of social workers in social assistance, strategies for social assistance, and the framework for conducting social assistance (Suharto, 2017). Empowerment strategies include agricultural development, rural industrialization, and integrated rural development (Onny S. Priyono, 1996).

Coconut is the main plantation commodity in Banyumas Regency. In 2016, the area of coconut plantations was $12,658.55$ ha and deres coconut 5,015.60 ha. Copra production is $13,283.89$ tons/year while coconut sugar production is $54,730.50$ tons/year or production capacity is 155 tons/day with 28,030 penderes. Banyumas Regency is even claimed to be the largest producer of coconut sugar globally (Widyarto, 2021). However, there are still many penderes in Banyumas Regency whose less prosperous lives.

LPPSLH is a non-government institution engaged in rural and urban empowerment. LPPSLH, as a facilitator, invites the farmers to participate in the organic palm sugar certification program. The 
participation will later increase the income of the penderes and support their products to the export market. Training and direction are carried out to change the behavior of farmers from old habits to new habits that are more productive and profitable.

Research on the empowerment of penderes is necessary because empowerment allows the potential of the community to develop, strengthens the potential of the community, and protects the poor. These three things are the main essence of community empowerment. Therefore, this study aims to describe how the role of LPPSLH in empowering penderes in Pasinggangan village, Banyumas district, and how the empowerment process takes place, and efforts to build selfreliance of penderes or coconut sugar farmers.

\section{METHOD}

The research subjects were the penderes and the facilitators from LPPSLH in Pasinggangan Village, Banyumas. This research is qualitative research with a descriptive approach. Qualitative research aims to understand phenomena about what is experienced by research subjects such as perception, behavior, motivation, etc. The descriptive approach is used to describe how the role of LPPSLH in the empowerment process and efforts to build fisherman independence. The sampling was collected purposively. The data collection technique used interviews, observation, and documentation. The analytical technique used is the interactive analysis method.

\section{RESULTS AND DISCUSSION}

The writing below will be discussed related to the analysis and discussion of research on the role of NGO in community empowerment.

\subsection{Coconut Sugar Empowerment Program}

Seeing the various problems faced by penderes, LPPSLH was encouraged to carry out an empowerment program in Pasinggangan village. The coconut sugar farmer or penderes is a rural work program implemented by LPPSLH. This program is engaged in organic farming, which aims to improve the welfare of the farmers. The target of this empowerment program is the penderes that produce coconut sugar. Empowerment is carried out in the form of continuous assistance and improvement of the quality of coconut sugar artisans and improving the quality of coconut sugar products. Activities carried out are socialization, training, and assistance regarding organic certification, improving sugar quality, making ant sugar, and market access.

LPPSLH implements a coconut sugar empowerment program, cooperates with institutions from abroad and domestic to provide financial access (funding). In this empowerment program, LPPSLH also invites district and village governments and community leaders to participate in the coconut sugar business development in Pasinggangan village. Collaboration from various parties is needed to support the implementation of community empowerment programs.

The empowerment process is carried out through several stages: regional assessment, program socialization, training, organic certification, market access development, and monitoring and evaluation. Regional assessment is the first step in the community empowerment program before determining the program's target area. The regional assessment aims to see aspects that exist in the program target area. These aspects are the potential of the area, the number of penderes and the condition of the land. 
After assessing and determining program target areas, program socialization is next. The socialization was carried out in Pasinggangan village to dig up information regarding the needs of the villager about the quality and improvement of the villager's welfare. The next process is the training, which aims to provide direct understanding to farmers regarding good and profitable coconut sugar business management.

Organic certification is one of the processes in which organic certification is a strategic step taken by LPPSLH to increase the income and welfare of farmers. The organic label in coconut sugar products is an added value and opens wider market access to foreign countries. The organic certificate will indirectly increase the value of coconut sugar to the global market. The certification process involves the penderes, the ICS (Internal Control System) team, and the organic certificate issuing agency. LPPSLH itself in the organic certification process plays a role in assisting the ICS team in preparing, assisting, and supervising during the organic certification program.

The first step of empowerment carried out by LPPSLH in Pasinggangan village is by cutting the market chain. It is due to the limited market access owned by penderes. First, penderes could only sell their products to one collector because they were tied to the ijol system. The ijol system is very detrimental to the farmers. In addition to closing the market access for the farmers, the ijol system also causes the farmers to have no bargaining power over the selling price of sugar. The price of sugar in the ijol system is under the control of the collectors. The marketing flow before empowerment is described as follows:

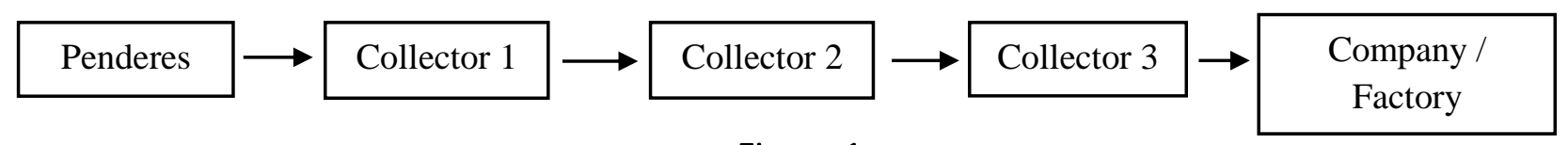

Figure.1

\section{Coconut Sugar Marketing Flow Before Empowerment}

Based on the chart, it can be seen that the market access owned by penderes is very narrow and limited. Penderes sell to one collector only. The long distribution process causes the price of sugar from the penderes to below. This condition is exacerbated by the ijol system, which forcibly applies the selling price of sugar from the penderes due to burdensome obligations.

The market chain approach is the approach taken by LPPSLH for small-scale collectors against market collectors. If the seller initially sells a product to collectors through this approach, the seller can directly sell products or consumers without going through collectors again. However, this approach was later due to getting from local collectors. In addition, it was found that the collectors who took sugar from the penderes in Pasinggangan village also mostly had a mediocre economy. Increasing the chain's value is then changed to a chain approach. The value chain works by involving parties involved in the coconut sugar industry. Collectors are no longer left to pay attention to maintaining the marketing of coconut sugar. In this approach, the farmers have a bargaining position on the price of coconut sugar because the collectors no longer control it. Cooperatives in this approach also have a role in keeping the price of coconut sugar stable. The cooperative understands with local collectors to determine the price of coconut sugar. This approach is the first step to make changes in market access that were previously closed to become more open. Changes in the marketing flow of coconut sugar products after empowerment can be described as follows: 


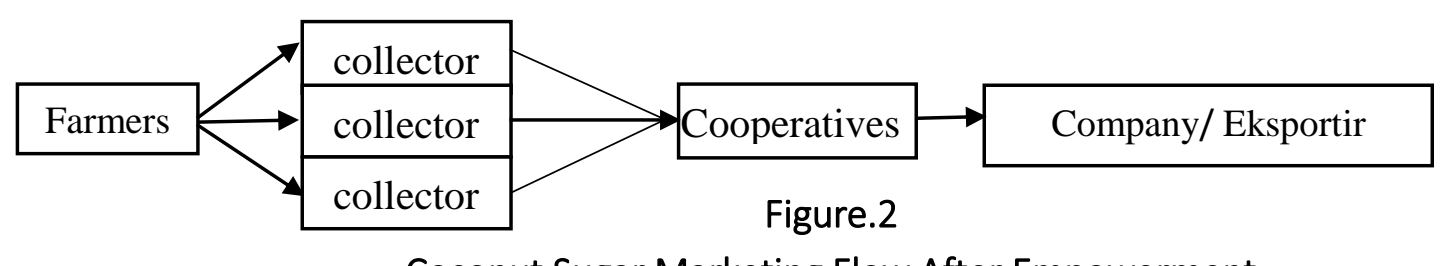

Coconut Sugar Marketing Flow After Empowerment

From the chart, it can be seen that the marketing flow of coconut sugar has changed. Farmers no longer use one collector but can sell their products to several collectors and even sell directly to cooperatives and export companies. The impact of the marketing channel is that there is a change in market access that makes farmers more independent and not dependent on collectors. Furthermore, 'monitoring and evaluation activities are the final steps in empowering coconut sugar. This activity is also known as the impact and results of the program of empowerment activities carried out in Pasinggangan village, Banyumas Regency.

\subsection{The Role of LPPSLH in Empowerment}

Community empowerment carried out by LPPSLH is a way to explore and generate resources owned by farmers. Empowerment means cultivating the community's potential to give strength to the community so that the desired results can be achieved. In this empowerment process, LPPSLH acts as a facilitator to provide education, facilitation, and advocacy. Education aims to understand the audience about the goals to be achieved. Education is an important first step to building public awareness to make changes. LPPSLH also actively discusses with the villager community, especially by conducting mentoring programs.

LPPSLH performs a facilitation role as an intermediary or bridge between the farmers and the global market. LPPSLH facilitates farmers to expand their marketing of coconut sugar products to foreign countries through the palm sugar certification program. Facilitation is not only carried out for product marketing, but LPPSLH also acts as an intermediary between the farmers and the local government. LPPSLH facilitates the villager to convey their aspirations to the local government about the problems faced by the villager. The advocacy role carried out by LPPSLH is participating in the formulation of empowerment programs for penderes in Bappeda, Banyumas district. In addition, the form of advocacy is to encourage the government's contribution to the development of the coconut sugar business, such as providing training, assistance in constructing cooperative buildings and providing safety guarantees for farmers. LPPSLH, in this case, also plays a role in assisting penderes who want to apply for work safety guarantee assistance to the local government.

Independence is defined as the state of not being dependent on others. The independence referred to in this study is the independence of the penderes. The independence of the penderes is defined as a condition where the farmers have independent institutions in managing the coconut sugar business and can improve the welfare of themselves and their families. The formation of cooperatives and farmer groups can be evidence of the independence efforts carried out by LPPSLH against penderes in Pasinggangan village. 


\subsection{The Importance of the Role of Cooperatives in Empowering Villagers}

To empower penderes that is currently being carried out by LPPSLH, the organization of the penderes community or coconut sugar farmers is aimed to build a strong penderes cooperative institution and has a controlling role in the value chain. As the first step in organizing the penderes, a cooperative is formed whose members come from the village of the fishing group itself. According to Law No. 12 of 1967 concerning the Basics of the Economic, cooperatives are defined as economic organizations with a social character consisting of individuals or legal entities. Cooperative is an economic arrangement as a joint effort based on the principles of kinship and cooperation. The purpose of cooperatives is to promote the welfare of members and the community and participate in building the national economic order to create an advanced, just, and prosperous society (Sudarsono dan Edilius, 2004).

The cooperative strategy as a form of people's economy in obtaining better market access is to run a product guarantee system to improve the quality of coconut sugar and build cooperation with buyers. So, it will build a market network. In addition, high understanding will encourage fair relations between value chain actors. The value chain will increasingly open up equitable market access through cooperation between actors.

The increase in Panderes's income will strengthen cooperative institutions with savings and loan businesses. It will reinforce members' access to capital, thereby reducing debt to collectors. The decreasing dependence on collectors will increase farmers' bargaining position on the selling price of the product. Increasing the villager's capacity in household management will increase the ability to manage income. Ability to manage the economy is very important, so the penderes do not behave consumptively. It will certainly provide benefits because the crane can make the production cost-efficient by developing fuel-efficient stoves that can reduce the use of firewood which is currently scarce. The more production efficiency, the more it will encourage penderes to increase development. Therefore, LPPSLH organizes cooperatives to become examples for the welfare of the penderes community.

Through cooperatives, penderes want to get used to enjoying them to be stored in the cooperative. The results from these savings can be taken within a particular time and can also be used by cooperatives to help penderes who need credit. Independence is very important in supporting the coconut sugar business at the farmer's level. Through the independence of the penderes, the coconut business will continue to run even though the empowerment program carried out by LPPSLH has been completed so that there is no reward for penderes in Pasinggangan village.

\subsection{Responses of the Penderes Community in the Empowerment Program}

The interviews and observations showed that the empowerment process carried out by LPPSLH in Pasinggangan village received positive responses from the community, especially penderes in accepting assistance and training as well as changes made by LPPSLH. One of the penderes there named Mr. Sakum, said: "I am very grateful and very happy with the organic coconut sugar certification program, it can improve the economy of the farmers. At the past, penderes only thought that what was important was meeting their daily needs, meaning that if they 
sold $1 \mathrm{~kg}$ of sugar, they could buy $1 \mathrm{~kg}$ of rice too. With the organic certification, the price of sugar has increased well than before and met other needs, not just food needs.

On the other hand, there are obstacles to active participation among the community. The penderes are above 40 years on average, and the regeneration is still lacking. It is due to the lack of interest of young people in Pasinggangan village for penderes. They prefer urbanization to cities to find work.

\section{CONCLUSION}

Based on the discussion, it can be concluded that the condition of the penderes before the empowerment was in a difficult situation. Sugar prices tend to be low, sugar quality is dirty, and penderes are in debt with collectors making it difficult to get welfare. However, after the empowerment, there were several changes in the life aspects of the penderes as follows:

\begin{tabular}{|c|c|c|}
\hline Aspect & Before the empowerment & After the empowerment \\
\hline Sales price & $\begin{array}{l}\text { The selling price of coconut sugar is } \\
\text { very low, between Rp. 3,000 to Rp. } \\
8,000 \text { per kilo }\end{array}$ & $\begin{array}{l}\text { The price of coconut sugar } \\
\text { increased to Rp 12,000-To } \\
15,000 \text { (printed sugar) and Rp } \\
16,000-\text { Rp 20,000 (ant sugar) }\end{array}$ \\
\hline $\begin{array}{l}\text { Coconut sugar } \\
\text { product quality }\end{array}$ & $\begin{array}{l}\text { There is no standardization of sugar } \\
\text { quality and contains chemicals }\end{array}$ & $\begin{array}{l}\text { There is already standardization } \\
\text { of coconut sugar and free of } \\
\text { chemicals }\end{array}$ \\
\hline Health & $\begin{array}{l}\text { Unhealthy kitchen conditions make } \\
\text { farmers vulnerable to ARI, and there } \\
\text { is no health insurance for farmers }\end{array}$ & $\begin{array}{l}\text { The condition of the kitchen } \\
\text { becomes healthy and farmers } \\
\text { are not susceptible to ARI and } \\
\text { there is health insurance for the } \\
\text { penderes (pass card) }\end{array}$ \\
\hline Market Access & $\begin{array}{l}\text { Products that are limited only to } \\
\text { collectors, plus they are in debt } \\
\text { which makes penderes dependent } \\
\text { on collectors }\end{array}$ & $\begin{array}{l}\text { Product marketing is becoming } \\
\text { wider to foreign countries }\end{array}$ \\
\hline Social & $\begin{array}{l}\text { There are no farmer groups and } \\
\text { cooperatives that support the } \\
\text { development of the coconut sugar } \\
\text { business }\end{array}$ & $\begin{array}{l}\text { The formation of farmer groups } \\
\text { and cooperatives that support } \\
\text { and become a forum for the } \\
\text { development of the coconut } \\
\text { sugar business }\end{array}$ \\
\hline
\end{tabular}

\section{REFERENCES}

Anwas. (2014). Pemberdayaan Masyarakat Di Era Global. Bandung: Alfabeta.

Hayami Yujiro dan Masao Kikuchi, (1987). Dilema Ekonomi Desa: Suatu Pendekatan Ekonomi terhadap Perubahan Kelembagaan di Asia. Yogyakarta: YOI hal. 11.

Jim Ife dan Frank Tesoriero. (2008). Community Development: Alternatif Pengembangan Masyarakat di Era Globalisasi. Yogyakarta: Pustaka Belajar. 
Koentjaraningrat. (1973). Metode-metode Penelitian Masyarakat. Jakarta: PT Gramedia.

Kuncoro, Bambang. (2004). Diktat Kuliah Pemberdayaan Masyarakat Desa. Purwoketo: Fisip Unsoed.

Mardikanto, Totok. (2010). Konsep-konsep Pemberdayaan Masyarakat. Bandung: Alfabeta.

Mashuri Maschab, (1992). Pemerintahan Desa di Indonesia. Yogyakarta: UGM Press.

Milles, Matthew dan Hubermasn, A. Michael. (1992). Analisis Data Kualitatif. Jakarta: UI-Press.

Nasdian, Fredian Tonny. (2014). Pengembangan Masyarakat. Jakarta: Departemen Sains Komunikasi dan Pengembangan Masyarakat.

Priyono, Onny S. (1996). Pemberdayaan Konsep Kebijakan dan Implementasi. Jakarta: Centre for Strategic and International Studies.

Sudarsono dan Edilius. 2004. Manajemen Koperasi Indonesia. Jakarta: PT Rineka Cipta.

Suharto, Edi. (2017). Membangun Masyarakat Rakyat Memberdayakan Rakyat Kajian Strategis Pembangunan Kesejahteraan Sosial dan Pekerjaan Sosial. Bandung: PT Refika Aditama.

Usman, Sunyoto. 1998. Pembangunan dan Pemberdayaan Masyarakat. Yogyakarta: Pustaka Pelajar. Wiajaya, Mahendra. 2010. Kemiskinan dan Pemberdayaan Masyarakat Desa. Journal of Rural and Development,

Widyarto, Regenerasi Penderes, (Kasi Tanaman Tahunan Dinas Pertanian dan KP Kab. Banyumas), jurnal dinas pertanian, dinpertankp.banyumaskab.gp.id-read-regenerasi-penderes hal 2. Diambil pada tanggal 23 Sepetember 2021 pukul 22.30 WIB.

http://www.Ippslh.or.id. 